\title{
Microbiological quality analysis of domestic water collected from the slum area's people in Dhaka city
}

\author{
Ifra Tun Nur*, Rakhi Baishnab and Niger Sultana Tethee \\ Department of Microbiology, Stamford University Bangladesh, 51 Siddeswari Road, Dhaka 1217, Bangladesh
}

Received 16 July 2017/Accepted 19 August 2017

\begin{abstract}
Over the last few consecutive decades along with urbanization slum population has been raised. But unfortunately unsatisfactory water supply and sanitation systems are the main obstacles of their livelihood and they are suffering from many diseases. So our present study attempted to focus on the existence of pathogenic microorganisms in domestic water used by slum population along with drug resistant pattern of the isolated bacteria. Total 20 samples were collected and processed for microbiological action. Significant numbers of coliform bacteria especially Escherichia coli and Klebsiella spp. were found within the range of $10^{2}$ to $10^{4} \mathrm{cfu} / \mathrm{ml}$. Conversely almost all samples exhibited fecal contamination except sample 5 and 6. Growth of fungus and other pathogenic bacteria such as Staphylococcus spp. and Vibrio spp. also found in almost every sample. Total 10 available drugs were used against the identified isolates. Most of the identified bacteria were found to be sensitive against commonly used antibiotics. Resistance was found only against ampicilin, amoxycilin and vancomycin.
\end{abstract}

Key words: Microbiological analysis; Domestic water; Hand washed water; Slum area’s people

Water is one of the most essential elements for us to live and to do our daily activities. About 160 million people live in Bangladesh in which almost 13\% lack safe water and $39 \%$ lack proper sanitation. Along with urbanization a mass population migrated from village for their livelihood and started living in slum area. Approximately 863 million people globally live in urban slums (1). Only in Dhaka city around 5.3 million people are living in nearly 400 urban slums. Slum is a cluster of habitat consist of unsystematically and unhealthy atmosphere where people deprived of having potable water supply, lacking of drainage system for standard living, insecurity of tenure poor unsanitary conditions and suffering from various waterborne and food borne diseases. At present situation water- borne illness, caused by fecal contamination of water, is major health burden in our country in slum area. Many city centrally supplies chlorinated water, therefore (2-5), when people living is slum collect water from tap, the chances of bacterial contamination may be less common. However unsafe water storage system and point of collecting water are the reasons behind fecal contamination (6-8). Sometimes leaked underground pipeline merge with sewage line and causes fecal contamination in addition industrial and agricultural waste water runoff with rain water and mixed up with potable water $(6,8)$. Particularly in low income

*Corresponding Author: Mailing address. Ifra Tun Nur, Lecturer, Department of Microbiology, Stamford University Bangladesh, 51 Siddeswari Road, Dhaka 1217, Bangladesh, Bangladesh; E-mail: ifra.tun@stamforduniversity.edu.bd. countries, $88 \%$ of diarrheal deaths are attributable to unsafe water, inadequate sanitation and poor hygienic condition or knowledge and lack of awareness (9). In slum areas, people struggle to obtain access to safe water. Pathogenic microorganism and fecal microorganisms mainly obtain from wastewater discharges in fresh water and costal seawater (10-13). In developing countries like Bangladesh acute microbial diarrheal diseases are a major public health concern. In slum poor hygienic facilities, financial crisis, scarce of resources, lack of education are also reasons behind diarrheal diseases. Children under five is the high risk group in Asian and African countries are the most affected by diseases transmitted through water borne pathogen $(14,15)$.

Water microbiologists and environmental experts are mainly concerned about enteric pathogens which are frequently disseminated in water sources (16). As a consequence, sources of fecal pollution in water bodies devoted to human activity must be strictly controlled. Within a diversified microflora enteric bacterial pathogen such as Escherischia coli $\mathrm{O} 157: \mathrm{H} 7$ is generally present at very low concentrations in environmental water. Detection of this pathogen are labor intensive and extremely time consuming $(16,17)$. In most of the cases coliform is present in huge array in the intestine of humans and other warm-blooded animals, and are thus found in fecal materials excreted from these sources. Frequency of short term gastrointestinal disorders and illnesses such as gastroenteritis, giardiasis, typhoid, dysentery, cholera, skin disease and hepatitis etc. has been noticed in slum people $(17,18)$. 
In Dhaka city, most of the slums have hanging latrines built over the water bodies which is making the water bodies polluted. When we visited the slum area we came to know that they collect their household water from tap and sometimes they collect rain water. Scarce of drinking water is a problem and contaminated household water causes serious illness as people use this water for cooking, washing utensils and clothes, bathing, washing hand and face and for toilet purpose. Females are especially suffering from urinary tract infection as they said in slum areas. Along these lines, present study was designed to chalk out the existence and multiplication of different pathogenic microorganisms in domestic water along with their resistant properties against antibiotics.

\section{MATERIALS AND METHODS}

Study area and sampling. Water was collected for testing from 20 different slum from Dhaka metropolis during the time period of April 2017 to May 2017. Samples were collected aseptically in sterile screw capped bottles maintaining in a thermal stabilizing box with a constant temperature of $25^{\circ} \mathrm{C}$, transported to the laboratory within one hour and immediately subjected to microbiological analysis (17-19).

Microbiological quality analysis of water samples. An aliquot of $0.1 \mathrm{ml}$ of each sample was introduced on to nutrient agar and sabouraud dextrose agar for the isolation of total viable bacteria count and fungal count. In case of specific gram positive and gram negative pathogenic bacteria same amount of sample water was inoculate on MacConkey agar, TCBS agar, MSA and MFC agar through spread plate technique for the isolation of total viable bacteria coliform (E. coli, Klebsiella spp.), Vibrio spp., ,Staphylococcus spp. and fecal coliform respectively. Plates were incubated at $37{ }^{\circ} \mathrm{C}$ for 24 hours excluding $\mathrm{mFC}$ agar plates which were incubated at $44.5^{\circ} \mathrm{C}$ and SDA at $25^{\circ} \mathrm{C}$. Presence of green metallic sheen on EMB agar media was further specified the presence of $E$. coli $(16,20-23)$. For the final identification all isolates were biochemically analyzed by following the standard methods $(24,25)$.

Antibiotic susceptibility test of the identified bacteria. The pathogenic isolates were examined for antibiotic susceptibility traits (either drug resistant or sensitive) by disc diffusion assay on Mueller-Hinton agar (Difco, Detroit, MI) against commonly used antibiotics following the standard protocol $(17,26,27)$. Antibiotics used in the study included trimethoprime/sulfamethoxazole $(25 \mu \mathrm{g})$, erythromycin $(15 \mu \mathrm{g})$, amoxicillin $(30 \mu \mathrm{g})$, ceftriaxon $(30 \mu \mathrm{g})$, ciprofloxacin (5 $\mu \mathrm{g})$, streptomycin $(10 \mu \mathrm{g})$, ampicillin $(10 \mu \mathrm{g})$, tetracycline $(30 \mu \mathrm{g})$, chloramphenicol $(30 \mu \mathrm{g})$, cefixime $(5 \mu \mathrm{g})$, polymixin $\mathrm{b}$ (300 units), kanamycine (30 $\mu \mathrm{g})$, vancomycin $(30 \mu \mathrm{g})$, gentamycin $(10 \mu \mathrm{g})$, nalidixic acid $(30 \mu \mathrm{g})$, azythromycin $(15 \mu \mathrm{g})$ and penicillin $\mathrm{G}(10 \mu \mathrm{g})$.

\section{RESULTS AND DISCUSSIONS}

Now a days water borne diseases are the great threat. Various types of pathogens can be transmitted through contaminated food and water including coliform, fecal coliform, Staphylococcus spp. and Vibrio spp. due to the poor sanitation and personal unhygienic condition those are the main causative agent of diarrhea and dysentery (17). Such diseases are very common in developing countries like Bangladesh, especially in slum area where the people are not educated as well as very insensible about the good sanitation $(16,17)$.

Existence of different pathogens. Among the 20 samples 16 samples were found to be contaminated with E. coli up to $10^{4} \mathrm{cfu} / \mathrm{ml}$ and 15 samples exhibited the existence of Klebsiella spp. upto $10^{3} \mathrm{cfu} / \mathrm{ml}$ (Table 1). 18 samples were contaminated with fungi up to $10^{5} \mathrm{cfu} / \mathrm{ml}$ and 14 samples among 20 were contaminated with Staphylococcus spp. and Vibrio spp. up to $10^{4}$ and $10^{3}$ $\mathrm{cfu} / \mathrm{ml}$, respectively. Most interesting think was the fecal contamination in hand. In most of the case the slum people are not much more concern even they don't care about the personal hygiene. Among the 20 samples only 2 samples 5 and 6 were found free from coliform and fecal contamination.

TABLE 1. Microbiological quality assessment of hand washing water

\begin{tabular}{|c|c|c|c|c|c|c|c|}
\hline \multirow{2}{*}{$\begin{array}{l}\text { Sample } \\
\text { No }\end{array}$} & \multicolumn{7}{|c|}{ Load of microorganisms (cfu/ml) } \\
\hline & TVB & Fungi & E. Coli & $\begin{array}{l}\text { Klebsiella } \\
\text { spp. }\end{array}$ & $\begin{array}{c}\text { Fecal } \\
\text { coliform }\end{array}$ & $\begin{array}{l}\text { Staphylococcus } \\
\text { spp. }\end{array}$ & Vibrio spp. \\
\hline 1 & $2.89 \times 10^{6}$ & $1.2 \times 10^{5}$ & $1.5 \times 10^{4}$ & $5 \times 10^{3}$ & $1.0 \times 10^{3}$ & $3 \times 10^{3}$ & $3 \times 10^{3}$ \\
\hline 2 & $3.0 \times 10^{6}$ & $2.0 \times 10^{5}$ & $1.2 \times 10^{4}$ & $6 \times 10^{3}$ & $7 \times 10^{3}$ & $2.0 \times 10^{3}$ & $5 \times 10^{3}$ \\
\hline 3 & $3.15 \times 10^{6}$ & $1.0 \times 10^{5}$ & $1.6 \times 10^{4}$ & $9 \times 10^{3}$ & $5 \times 10^{3}$ & 0 & $6 \times 10^{3}$ \\
\hline 4 & $2.9 \times 10^{6}$ & $8.0 \times 10^{4}$ & $2.5 \times 10^{4}$ & $12 \times 10^{3}$ & $2.0 \times 10^{3}$ & $1.0 \times 10^{3}$ & 0 \\
\hline 5 & $3.0 \times 10^{6}$ & $4 \times 10^{4}$ & 0 & 0 & 0 & $4 \times 10^{3}$ & $1 \times 10^{4}$ \\
\hline 6 & $1.5 \times 10^{6}$ & $6.0 \times 10^{5}$ & 0 & 0 & 0 & 0 & $2.0 \times 10^{3}$ \\
\hline 7 & $3.6 \times 10^{6}$ & $2.0 \times 10^{6}$ & $6 \times 10^{4}$ & $4 \times 10^{3}$ & $7.0 \times 10^{3}$ & $1.0 \times 10^{3}$ & $2 \times 10^{3}$ \\
\hline 8 & $2.5 \times 10^{6}$ & $5.5 \times 10^{5}$ & $4 \times 10^{4}$ & $6 \times 10^{3}$ & $3.0 \times 10^{3}$ & 0 & 0 \\
\hline 9 & $1.6 \times 10^{6}$ & $1 \times 10^{4}$ & $1.5 \times 10^{4}$ & $10 \times 10^{3}$ & $1.0 \times 10^{3}$ & 0 & $3 \times 10^{3}$ \\
\hline 10 & $1.5 \times 10^{4}$ & 0 & $1.0 \times 10^{3}$ & 0 & 0 & 0 & 0 \\
\hline 11 & $7.1 \times 10^{5}$ & 0 & 0 & 0 & 0 & 0 & 0 \\
\hline 12 & $5.0 \times 10^{5}$ & $2.0 \times 10^{5}$ & 0 & 0 & 0 & $6 \times 10^{3}$ & $7 \times 10^{3}$ \\
\hline 13 & $2.0 \times 10^{5}$ & $4.0 \times 10^{5}$ & $2.5 \times 10^{4}$ & $1 \times 10^{3}$ & $3.0 \times 10^{3}$ & $5 \times 10^{3}$ & $6 \times 10^{3}$ \\
\hline 14 & $2.0 \times 10^{5}$ & $1.2 \times 10^{5}$ & $5 \times 10^{3}$ & $3 \times 10^{3}$ & $5.0 \times 10^{3}$ & $5 \times 10^{3}$ & 0 \\
\hline 15 & $2.5 \times 10^{5}$ & $1.5 \times 10^{5}$ & $5 \times 10^{3}$ & $4 \times 10^{3}$ & $1.0 \times 10^{3}$ & $1 \times 10^{3}$ & $7 \times 10^{3}$ \\
\hline 16 & $3.0 \times 10^{5}$ & $2.0 \times 10^{5}$ & $5 \times 10^{4}$ & $5.9 \times 10^{3}$ & 0 & $2 \times 10^{3}$ & 0 \\
\hline 17 & $2.5 \times 10^{6}$ & $5.5 \times 10^{5}$ & $2 \times 10^{4}$ & $2.5 \times 10^{3}$ & $1.5 \times 10^{3}$ & $4.5 \times 10^{4}$ & $5 \times 10^{3}$ \\
\hline 18 & $2.5 \times 10^{6}$ & $5.5 \times 10^{5}$ & $2 \times 10^{4}$ & $2.5 \times 10^{3}$ & $1.5 \times 10^{3}$ & $4.5 \times 10^{4}$ & $5 \times 10^{3}$ \\
\hline 19 & $2.05 \times 10^{6}$ & $5.5 \times 10^{5}$ & $1 \times 10^{4}$ & $2.0 \times 10^{3}$ & $1.9 \times 10^{3}$ & $4.0 \times 10^{4}$ & $3 \times 10^{3}$ \\
\hline 20 & $2.0 \times 10^{6}$ & $5 \times 10^{5}$ & $1 \times 10^{4}$ & $2.0 \times 10^{3}$ & $1.0 \times 10^{3}$ & $4.0 \times 10^{4}$ & $2 \times 10^{3}$ \\
\hline
\end{tabular}

$\mathrm{TVB}=$ Total viable bacteria 
TABLE 2. Antibacterial susceptibility pattern of the isolates

\begin{tabular}{|c|c|c|c|c|c|c|c|c|c|c|}
\hline 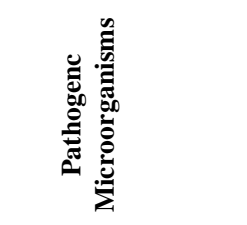 & 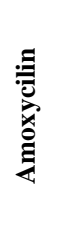 & 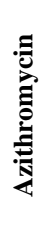 & 竞 & 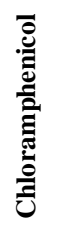 & 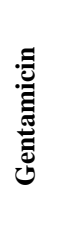 & 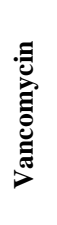 & 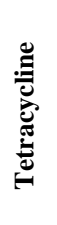 & 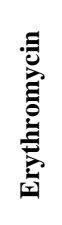 & 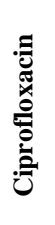 & 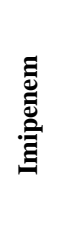 \\
\hline E. coli & $\mathrm{R}$ & S & $\mathrm{R}$ & $S$ & S & $\mathrm{R}$ & S & S & S & S \\
\hline Klebsiellaspp. & $\mathrm{R}$ & S & $\mathrm{R}$ & $S$ & S & $\mathrm{R}$ & S & S & S & I \\
\hline Vibrio spp. & $\mathrm{R}$ & S & $\mathrm{R}$ & $S$ & S & $\mathrm{R}$ & $\mathrm{R}$ & S & $\mathrm{R}$ & $\mathrm{R}$ \\
\hline Staphylococcus spp. & $\mathrm{R}$ & $S$ & $\mathrm{R}$ & S & S & $\mathrm{R}$ & $S$ & S & S & S \\
\hline
\end{tabular}

$\mathrm{R}=$ Resistant $\mathrm{S}$ = Sensitive I = Intermediate

Proliferation of drug-resistant bacteria in hand washing water. In this experiment the Kirby-Bauer disk diffusion test was used to make a decision whether the isolated organisms were susceptible or resistant to a selected pool of antimicrobial agents $(23,28)$. The study showed that, most of the isolates exhibited multidrug resistance (MDR) phenotype (Table 2). All the isolates were found to be highly resistant against Vancomycin (100\%) and Erythromycin (100\%). Vibrio spp. were found to be resistant against 7 different antibiotics and sensitive against azithromycin, chloramphenicol, gentamicin, whereas Salmonella spp. showed resistance against 5 different antibiotics whereas sensitive against chloramphenicol, gentamicin, tetracycline, ciprofloxacin. Resistance gene might be evolved due to point mutation, genetic disorders, and mechanistic factors or by epidemiological factors $(16$, $29,30)$.

\section{CONCLUSION}

Contaminated water is one of the major route of enteric diseases specially in developing countries people where the opportunities of good sanitary practices and public awareness is limited. In current research, we detected pathogenic bacteria including $E$. coli and Klebsiella spp. as coliform and also fecal contamination. Some of the samples were found to be contaminated with Staphylococcus spp and Vibrio spp which indicates the necessity of proper awareness of an individual's about the significant of hand washing before taking any food to ensure the health safety. Finally, this sort of surveillance would be suggestive for the public health department of the government to generate more public awareness program and free training for the uneducated and underprivileged people.

\section{CONFLICT OF INTEREST}

Authors have no conflict of interest.

\section{ACKNOWLEDGEMENT}

I do acknowledge Dr. Rashed Noor, Chairman, Department of Microbiology, Stamford University Bangladesh, for his kind support, encouraging advice and valuable guidance throughout the course of this work.

\section{REFERENCES}

1. UN-HABITAT. State of the world's cities 2012-13: prosperity of cities. Nairobi: United Nations Human Settlements Programme; 2013.

2. Cabral JP, Marques C. 2006. Faecal coliform bacteria in Febros river (Northwest Portugal): temporal variation, correlation with water parameters, and species identification. Environ. Monit. Assess. 118: 21-36.

3. Murage EWK, Ngindu AM. 2007. Quality of water the slum dwellers use: The case of a Kenyan slum. J. Urban Health. 84 (6): 829-838.

4. Subbaraman R, Shitole S, Shitole T, Sawant K, O'Brien J, Bloom DE, et al. 2013. The social ecology of water in a Mumbai slum: failures in water quality, quantity, and reliability. BMC Public Health. 13: 173.

5. Aiga H, Arai Y, Marui E, Umenai T. 1999. Impact of improvement of water supply on reduction of diarrheal incidence in a squatter area of Manila. Environ. Health Prev. Med. 4 (3): 111-6.

6. van Derslice J, Briscoe J. 1993. All coliforms are not created equal: a comparison of the effects of water source and in-house water contamination on infantile diarrheal disease. Water Resource Research. 29 (7): 1983-95.

7. Alam MJ. 2007. Water quality tests and behavioral factors of child diarrhoea in Dhaka slums. BRAC University Journal. 4 (1): 103-9.

8. Nogueira G, Nakamura CV, Tognim MCB, Filho BAA, Filho BPD 2003. Microbiological quality of drinking water of urban and rural communities, BrazilRevista de SaudePublica. 37 (2): 232-236.

9. Murray CJ, Lopez AD. 1997. Global mortality, disability, and the contribution of risk factors: Global Burden of Disease Study. Lancet. 349: 1436-1442.

10. WHO (World Health Organization). 2008. Guidelines for drinking-water quality, incorporating $1 \mathrm{st}$ and 2nd Addenda, Volume 1, Recommendations, 3rd Edition. WHO, Geneva, Switzerland.

11. Fenwick A. 2006. Waterborne Diseases - Could they be consigned to history science. 313: 1077-1081.

12. George I, Crop P, Servais P. 2001.Use of $\beta$-D-Galactosidase and $\beta$-D Glucuronidase activities for quantitative detection of total and faecal coliforms in wastewater. Can. J. Microbiol. 47: 670-675.

13. Grabow WOK. 1996. Waterborne Disease.(1996).Update on water quality 
assessment and control. Water SA. 22: 193-202.

14. Subbaraman R, Nolan L, Sawant K, Shitole S, Shitole T, Nanarkar M, et al. 2015. Multidimensional measurement of household water poverty in a Mumbai slum: Looking beyond water quality. PLOS ONE. 10 (7): e0133241.

15. Seas C, Alarcon M, Aragon JC, Beneit S, Quiñonez M, Guerra H, et al. 2004. Surveillance of bacterial pathogens associated with acute diarrhea in Lima, Peru. Int. J. Infect. Dis. 4: 96-99.

16. Acharjee M, Jahan F, Rahman F and Noor R 2013 Bacterial proliferation in municipal water supplied in Mirpur locality of Dhaka city, Bangladesh. Clean - Soil , Air, Water. 42 (4): 434-441.

17. Munshi SK, Rahman MM, Noor R. 2012. Detection of virulence potential of diarrheagenic Escherichia coli isolated from surface water rivers surrounding Dhaka city. J. Bang. Acad. Sci. 36 (1): 109-122.

18. Rompre'A, Servais P, Baudart J, de-Roubin M , Laurent P. 2002 Detection and enumeration of coliforms in drinking water: current methods and emerging approaches. J. Microbiol. Methods. 49: 31-54.

19. Acharjee M, Rahman F, Beauty SA, Feroz F, Rahman MM, Noor R. 2012. Microbiological study on supply water and treated water in Dhaka city, S. J. Microbial. 1 (1): 42-45.

20. Colwell RR, Grimes DJ. 2000. Non-culturable microorganisms in the environment. American Society of Microbiology, Washington DC, USA

21. Oliver JD. 2010. Recent findings on the viable but nonculturable state in pathogenic bacteria. FEMS Microbiol. Rev. 34: 415-425.
22. Rahman F, Noor R. 2012. Prevalence of pathogenic bacteria in common salad vegetables of Dhaka metropolis. Bang. J. Bot. 41 (2): 159-162.

23. Noor R, Acharjee M, Ahmed T, Das KK, Paul L, Munshi SK, et al. 2013. Microbiological study of major sea fish available in local markets of Dhaka city, Bangladesh.J. Microbiol. Biotech. Food Sci. 2 (4): 2420-2430.

24. Alfrad EB. 2007. Bensons microbiological applications. Mcgraw-Hill Book Company, New York.

25. Cappuccino JG, Sherman N. 1996. Microbiology- A Laboratory Manual.The Benjamin/ Cummings publishing Co., Inc., Menlo Park, California.

26. Bauer AW, Kirby WMM, Sherris JC, Tierch M. 1966. Antibiotic susceptibility testing by a standardized single disc method. Ame. J. Clin. Patholog. 45 (4): 493-496.

27. Ferraro MJ, Craig WA, Dudley MN. 2001. Performance standards for antimicrobial susceptibility testing. NCCLS, Pennsylvania, USA.

28. Malek M, Akter J, Ahmed T and Uddin MA. 2015. Isolation and quantification of microorganisms from some common milk products within Dhaka city, Bangladesh. Stam. J Microbiol. 5 (1): 13-17.

29. Bennett PM. 2008. Plasmid encoded antibiotic resistance: Acquisition and transfer of antibiotic resistance genes in bacteria. Bri. J. Pharma. 153 (1): 347 357.

30. Canton R. 2009. Antibiotic resistance genes from the environment: A perspective through newly identified antibiotic resistance mechanisms in clinical setting. Euro. Soc. Clin. Microbiol. Infect. Dis. 15 (1): 20-25. 